CURRENT

Jurnal Kajian Akuntansi dan Bisnis Terkini

https://current.ejournal.unri.ac.id

\title{
STRUKTUR MODAL DAN NILAI PERUSAHAAN : DIPENGARUHI OLEH UNIQUENESS, TANGIBILITY DAN FINANCIAL FLEXIBILITY
}

\section{Delfi Agustiawan ${ }^{1}$, Yulia Efni ${ }^{2}$, Gusnardi Gusnardi ${ }^{3}$ \\ ${ }^{1,2}$ Program Studi Magister Manajemen, Fakultas Ekonomi dan Bisnis, Universitas Riau, Pekanbaru. \\ ${ }^{3}$ Program Studi Magister Akuntansi, Fakultas Ekonomi dan Bisnis, Universitas Riau, Pekanbaru. \\ *E-mail: delvi.agustiawan@yahoo.com}

\begin{tabular}{l} 
Keywords \\
\hline Uniqueness, \\
Tangibility, \\
Financial Flexibility, \\
Struktur Modal, \\
Nilai Perusahaan \\
\hline
\end{tabular}

\section{Article informations}

Received:

2020-08-30

Accepted:

2021-07-23

Available Online:

2021-07-31

\begin{abstract}
This study is aimed to examine the effect of uniquenss, tangibility and financial flexibility on capital structure and firm value. The population of this study is miscellaneous industry sector from 20152019. The sample of the study is all companies were selected by purposive sampling method. Based on the criteria, 33 companies were chosen as the samples of this study. This study used structural equation modeling with partial least square program to test whether the independent variables affect the dependent variables. The results of this study are found that (1) uniqueness has a negative and insignificant effect on capital structure, (2) tangibility has a positive and significant effect on capital structure, (3) financial flexibility has a positive and significant effect on capital structure, (4) uniqueness and tangibility have a positive and significant effect on firm value, whille financial flexibility has a negative and insignificant effect on firm value, (5) tangibility has a positive and significant effect on firm value through capital structure, while uniqueness dan financial flexibility have a negative and insignificant effect on firm value through capital structure, and (6) capital structure has a negative and significant effect on firm value.
\end{abstract}

\section{PENDAHULUAN}

Sektor aneka industri di Bursa efek Indoensia merupakan perusahaan yang menghasilkan produk yang dikonsumsi banyak orang sehingga para produsen dalam industri ini memiliki tingkat penjualan yang tinggi yang berdampak pula pertumbuhan perusahaan Bank Indonesia (2018) dalam laporan perekenomian Indonesia menjelaskan bahwa sektor aneka industri menjadi sektor dengan tingkat kemampuan memberikan keuntungan kepada investor lebih tinggi dibandingkan sektor lainnya, selain itu, BPS (2018) menyebutkan bahwa sektor industri masih menjadi kontributor terbesar bagi Produk Domestik Bruto (PDB) Indonesia yaitu sebesar 19,82\%.

Agar dapat bertahan dan berdaya saing baik dalam wilayak domestik maupun diluar domestik, perusahaan-perusahaan dalam industri harus dapat mempertahankan nilai yang 
baik, agar investor tetap memiliki persepsi yang baik terhadap kelangsungan hidup perusahaan. Oleh karena itu, nilai perusahaan menjadi perhatian khusus bagi perusahaan. Nilai perusahaan yang tinggi akan mencerminkan tingginya tingkat kemakmuran pemilik dan pemegang saham perusahaan (Permatasari \& Azizah, 2018). Adapun perkembangan nilai perusahaan pada sektor aneka industri di Bursa Efek Indonesia periode 2015-2019, dapat dilihat dari tabel 1 berikut ini:

Tabel 1

Perkembangan PBV dan DER Pada Sektor Aneka Industri Periode 2015 - 2019

\begin{tabular}{ccccc}
\hline Tahun & PBV & Perkembangan & DER & Perkembangan \\
\hline 2015 & 0,75 & - & 0,71 & - \\
2016 & 0,74 & $-1,35 \%$ & 0,73 & $2,74 \%$ \\
2017 & 0,71 & $-4,23 \%$ & 0,77 & $5,19 \%$ \\
2018 & 0,69 & $-2,90 \%$ & 0,84 & $8,33 \%$ \\
2019 & 0,65 & $-6,15 \%$ & 1,01 & $16,83 \%$ \\
\hline
\end{tabular}

Sumber: Laporan Keuangan 2015-2019.

Tabel 1 menunjukkan bahwa perusahaan-perusahaan pada sektor aneka industri mengalami penurunan selama 5 tahun terakhir dan industri ini rata-rata memiliki nilai perusahaan yang berada dibawah nilai 1 (satu) berturut-turut sejak tahun 2015 sampai dengan tahun 2019. Hal ini menunjukkan bahwa nilai perusahaan pada sektor ini masih masih rendah.

Nilai PBV yang rendah menunjukkan bahwa rendahnya harga saham dan akan mencerminkan rendahnya pula nilai perusahaan tersebut. Rendahnya nilai perusahaan menunjukkan bahwa semakin tidak baiknya prospek perusahaan dimasa yang akan datang, karena dianggap tidak begitu berhasil menggunakan keuangan perusahaannya. (Purwohandoko, 2017). Nilai perusahaan yang rendah menjadi perhatian khusus bagi manajemen perusahaan karena dapat disebabkan oleh adanya perubahan pada kombinasi modal. Kombinasi modal berubah apabila hutang perusahaan terlalu besar, maka harus perusahaan tidak dapat menambahan hutang baru lagi karena pada titik tertentu peningkatan hutang akan menurunkan nilai perusahaan.

Tabel 1 Juga menunjukkan nilai penggunaan hutang pada perusahaan di sektor ini menunjukkan peningkatan dari tahun 2015 sampai 2019. Meningkatnya nilai DER ini menunjukkan komposisi jumlah hutang/kewajiban lebih besar dibandingkan dengan jumlah seluruh modal bersih yang dimilikinya, sehingga mengakibatkan beban perusahaan terhadap pihak luar besar juga. Penggunaan hutang yang berlebihan dapat memberikan risiko keuangan yang berakibat pada buruknya nilai perusahaan.

Struktur modal dan nilai perusahaan dapat dipengaruhi oleh keunikkan (uniqueness) suatu perusahaan. Ketika produk unik yang ditawarkan perusahaan diterima masyarakat karena produk memberikan keuntungan bagi masyarakat dan secara konsisten menciptakan 
produk tersebut berulang-ulang maka akan menarik perhatian masyarakat luas. Perusahaan semakin memperoleh banyak dana untuk ekspansi dan melakukan inovasi terhadap produk uniknya, maka akan meningkatkan kemampuan perusahaan memperoleh laba yang akhirnya akan meningkatkan nilai perusahaan (Hoberg \& Phillips, 2012), namun perusahaan juga mengalami kesusahan untuk meminjam dana karena penggunaan modal mereka secara spesifik mengurangi kemungkinan pendanaan alternatif ketika terjadi kebangkrutan. Perusahaan dengan produk yang unik biasanya menghabiskan dananya pada resource and development $(\mathrm{R} \& \mathrm{D})$ agar membuat produk mereka semakin susah untuk ditiru dan memiliki biaya penjualan yang tinggi akibat promosi produk yang unik tersebut. Hal ini menyebabkan uniqueness memberikan pengaruh negatif terhadap struktur modal. Chunhua \& Meiyan, (2013) menjelaskan bahwa tingkat keunikan produk yang dimiliki oleh perusahaan akan menurunkan kemampuan perusahaan untuk memperoleh pendanaan dari hutang sehingga akan mempengaruhi komposisi struktur modal perusahaan.

Faktor lainnya yang dapat mempengaruhi struktur modal dan nilai perusahaan adalah aset berwujud (tangibility). Perusahaan yang memiliki aset berwujud yang lebih banyak, mampu memberikan jaminan yang lebih baik kepada pihak perbankan dan lembaga keuangan lainnya sehingga dapat meningkatkan kemampuan perusahaan untuk memperoleh pendanaan yang berasal dari hutang dan akan mempengaruhi komposisi dari struktur modal perusahaan dan nilai perusahaan (Jooma \& Gwatidzo, 2013).

Struktur modal dan nilai perusahaan juga dapat dipengaruhi oleh fleksibilitas keuangan (financial flexibility). Fleksibilitas keuangan adalah kemampuan perusahaan untuk memperoleh sumber daya keuangan agar memiliki kekuatan yang tepat dalam menghadapi kejadian masa depan yang tidak terduga dan untuk memaksimalkan nilai perusahaan. Fleksibilitas keuangan membantu perusahaan untuk mencegah kerusakan nilai dan memberikan perusahaan kemampuan untuk mengeksploitasi peluang investasi yang menjanjikan sehingga meningkatkan nilai perusahaan (Hoberg \& Phillips, 2012).

Berdasarkan latar belakang yang telah dijelaskan diatas, maka dapat ditarik rumusan masalah penelitian ini adalah sebagai berikut: 1) apakah uniqueness, tangibility dan financial flexibility berpengaruh terhadap struktur modal?, 2) apakah uniqueness, tangibility dan financial flexibility berpengaruh terhadap nilai perusahaan?, 3) apakah uniqueness, tangibility dan financial flexibility berpengaruh terhadap nilai perusahaan melalui struktur modal? dan 4) apakah struktur modal berpengaruh terhadap nilai perusahaan?.

Adapun tujuan yang hendak dicapai dari penelitian ini adalah sebagai berikut: 1) untuk menganalisa secara empiris pengaruh uniqueness, tangibility dan financial flexibility terhadap 
struktur modal, 2) untuk menganalisa secara empiris pengaruh uniqueness, tangibility dan financial flexibility terhadap nilai perusahaan, 3) untuk menganalisa secara empiris pengaruh uniqueness, tangibility dan financial flexibility terhadap nilai perusahaan melalui struktur modal, dan 4) untuk menganalisa secara empiris pengaruh struktur modal terhadap nilai perusahaan.

\section{PENGEMBANGAN HIPOTESIS}

\section{Pengaruh Uniqueness Terhadap Struktur Modal}

Resoursed based theory menjelaskan bahwa perusahaan dapat memperoleh keunggulan bersaingnya ketika perusahaan mengimplementasikan sebuah strategi menciptakan nilai bukan secara bersama-sama diimplementasikan oleh perusahaan pesaing. Perusahaan dapat memperoleh keunggulan bersaing berkelanjutan ketika perusahaan menciptakan strategi/produk yang bernilai dan tidak dapat ditiru oleh perusahaan lainnya (Barney, 1991).

Sumber daya yang unik dan sulit ditiru menciptakan produk/jasa yang unik dan terkhusus. Perusahaan dengan produk yang unik berpotesis membebankan biaya kepada pelanggan, pemasok dan pekerja ketika perusahaan mengalami likuidasi. Perusahaan juga mengalami kesusahan untuk meminjam dana karena penggunaan modal mereka secara spesifik mengurangi kemungkinan pendanaan alternatif ketika terjadi kebangkrutan. Perusahaan dengan produk yang unik biasanya menghabiskan dananya pada resource and development $(\mathrm{R} \& \mathrm{D})$ agar membuat produk mereka semakin susah untuk ditiru dan memiliki biaya penjualan yang tinggi akibat promosi produk yang unik tersebut. Hal ini menyebabkan uniqueness memberikan pengaruh terhadap struktur modal. Berdasarkan uraian tersebut, maka dapat dirumuskan hipotesis penelitian sebagai berikut:

\section{$\mathrm{H}_{1}$ : Terdapat pengaruh yang signifikan uniqueness terhadap struktur modal.}

\section{Pengaruh Tangibility Terhadap Struktur Modal}

Teori agensi berfokus pada penyelesaian dua masalah yang dapat terjadi pada hubungan agensi itu sendiri. Munculnya masalah keagenan ini ketika adanya konflik antara tujuan principal dan agentsdan sulit atau mahal bagi principal untuk memastikan apa yang sebenarnya terjadi pada agent tersebut (Eisenhardt, 1989). Berdasarkan teori keagenan ini, akan muncul dorongan pada pemegang saham untuk berinvestasi secara tidak optimal karena adanya konflik antara kreditur dan pemegang saham. Kecenderungan ini membuat kreditur akan melakukan tindakan untuk melindungi diri mereka dengan mengharuskan aset berwujud sebagai jaminan (Chakraborty, 2010). 
Berdasarkan teori keagenan ini, akan muncul dorongan pada pemegang saham untuk berinvestasi secara tidak optimal karena adanya konflik antara kreditur dan pemegang saham. Kecenderungan ini membuat kreditur akan melakukan tindakan untuk melindungi diri mereka dengan mengharuskan aset berwujud sebagai jaminan (Chakraborty, 2010). Perusahaan dengan tingkat aset berwujud yang tinggi akan memiliki jaminan untuk berhutang, jika perusahaan gagal membayar maka aset berwujud tersebut akan ditahan dan perusahaan terhindar dari kebangkrutan. Oleh karena itu ada terdapat hubungan positif antara banyak/tinggi nilai aset berwujud perusahaan pada kemampuan berhutang perusahaan. Berdasarkan uraian tersebut, maka dapat dirumuskan hipotesis penelitian sebagai berikut:

\section{$\mathrm{H}_{2}$ : Terdapat pengaruh yang signifikan tangibility terhadap struktur modal.}

\section{Pengaruh Financial Flexibility Terhadap Struktur Modal}

Signalling theory menyatakan bahwa setiap event atau kejadian yang berupa pengumuman, aksi korporasi, atau publikasi mengenai sebuah perusahaan baik yang disengaja maupun tidak disengaja akan memiliki muatan informasi sebagai suatu sinyal yang disampaikan kepada pasar (Brigham dan Houston, 2006). Salah satu cara untuk mengurangi informasi asimetris adalah dengan memberikan sinyal kepada pihak luar yaitu memberikan informasi keuangan yang dapat dipercaya dan memiliki integritas dan akan mengurangi ketidak pastian mengenai prospek perusahaan yang akan datang (Juliana, 2012).

Publikasi keuangan perusahaan dapat memberikan signal kepada pihak luar perusahaan mengenai keadaan perusahaan sebenarnya. Perusahaan akan mengelola kekuatan keuangan mereka melalui financial slack (keadaan dimana perusahaan memiliki dana yang berlebih) seperti uang tunai, aset riil dan sekuritas dipasar (Cherkasova \& Kuzmin, 2018). Oleh karena itu, perusahaan yang memiliki fleksibilitas keuangan yang lebih tinggi akan mencerminkan bahwa perusahaan memiliki tingkat hutang yang rendah. Berdasarkan uraian tersebut, maka dapat dirumuskan hipotesis penelitian sebagai berikut:

\section{H3: Terdapat pengaruh yang signifikan flexibility financial terhadap struktur modal.}

\section{Pengaruh Uniqueness Terhadap Nilai Perusahaan}

Resoursed based theory menjelaskan bahwa perusahaan dapat memperoleh keunggulan bersaing berkelanjutan ketika perusahaan menciptakan strategi/produk yang bernilai dan tidak dapat ditiru oleh perusahaan lainnya (Barney, 1991). Sumber daya yang unik dan sulit ditiru menciptakan produk/jasa yang unik dan terkhusus. 
Ketika produk unik yang ditawarkan perusahaan diterima masyarakat karena produk memberikan keuntungan bagi masyarakat dan secara konsisten menciptakan produk tersebut berulang-ulang maka akan menarik perhatian masyarakat luas (Hoberg \& Phillips, 2012). Produk unik menjadi dikenal secara global akan meningkatkan profitabilitas perusahaan. Peningkatan ini tentu akan menarik perhatian investor. Investor akan menanamkan modalnya pada perusahaan, perusahaan semakin memperoleh banyak dana untuk ekspansi dan melakukan inovasi terhadap produk uniknya, maka akan meningkatkan kemampuan perusahaan memperoleh laba yang akhirnya akan meningkatkan nilai perusahaan Berdasarkan uraian tersebut, maka dapat dirumuskan hipotesis penelitian sebagai berikut:

\section{$\mathrm{H}_{4}$ : Terdapat pengaruh yang signifikan uniqueness terhadap nilai perusahaan.}

\section{Pengaruh Tangibility Terhadap Nilai Perusahaan}

Teori agensi berfokus pada penyelesaian dua masalah yang dapat terjadi pada hubungan agensi itu sendiri.Berdasarkan teori keagenan ini, akan muncul dorongan pada pemegang saham untuk berinvestasi secara tidak optimal karena adanya konflik antara kreditur dan pemegang saham. Kecenderungan ini membuat kreditur akan melakukan tindakan untuk melindungi diri mereka dengan mengharuskan aset berwujud sebagai jaminan (Chakraborty, 2010). Aset berwujud adalah sumber daya yang digunakan sebagai jaminan atas hutang-hutang perusahaan selain itu aset berwujud akan mengurangi ketimpangan informasi dan dapat mengurangi risiko penyimpangan perilaku yang dilakukan oleh manajemen perusahaan. Konsekuensinya adalah perusahaan dengan aset berwujud yang sedikit akan memiliki kesusahan untuk memperoleh pendanaan dengan utang dan sebaliknya perusahaan yang memiliki aset berwujud yang lebih banyak, mampu memberikan jaminan yang lebih baik kepada pihak perbankan dan lembaga keuangan lainnya sehingga dapat meningkatkan kemampuan perusahaan untuk memperoleh pendanaan yang berasal dari hutang dan akan mempengaruhi komposisi dari struktur modal perusahaan dan nilai perusahaan(Jooma \& Gwatidzo, 2013). Berdasarkan uraian tersebut, maka dapat dirumuskan hipotesis penelitian sebagai berikut:

\section{H5: Terdapat pengaruh yang signifikan tangibility terhadap nilai perusahaan.}

\section{Pengaruh Financial Flexibility Terhadap Nilai Perusahaan}

Signalling theory menyatakan bahwa setiap event atau kejadian yang berupa pengumuman, aksi korporasi, atau publikasi mengenai sebuah perusahaan baik yang disengaja maupun tidak disengaja akan memiliki muatan informasi sebagai suatu sinyal yang disampaikan kepada pasar (Brigham dan Houston, 2006). 
Fleksibilitas keuangan menciptakan nilai perusahaan dalam dua hal yaitu dengan membantu perusahaan menghindari biaya langsung atau tidak langsung dari kesulitan keuangan dan menyediakan kemampuan bagi perusahaan untuk berinvestasi pada sumbersumber daya yang tersedia atau membantu perusahaan untuk menghindari biaya kesempatan dari kesulitan keuangan. Fleksibilitas keuangan memberi perusahaan kemampuan untuk menghindari semua biaya ini.Oleh karena itu, fleksibilitas keuangan membantu perusahaan untuk mencegah kerusakan nilai dan memberikan perusahaan kemampuan untuk mengeksploitasi peluang investasi yang menjanjikan sehinggameningkatkan nilai perusahaan(Hoberg \& Phillips, 2012). Berdasarkan uraian tersebut, maka dapat dirumuskan hipotesis penelitian sebagai berikut:

\section{H6: Terdapat pengaruh yang signifikan flexibility financial terhadap struktur modal.}

\section{Pengaruh Uniqueness Terhadap Nilai Perusahaan Melalui Struktur Modal}

Resoursed based theory menjelaskan bahwa perusahaan dapat memperoleh keunggulan bersaingnya ketika perusahaan mengimplementasikan sebuah strategi menciptakan nilai bukan secara bersama-sama diimplementasikan oleh perusahaan pesaing. Perusahaan dapat memperoleh keunggulan bersaing berkelanjutan ketika perusahaan menciptakan strategi/produk yang bernilai dan tidak dapat ditiru oleh perusahaan lainnya (Barney, 1991).

Keunikkan produknya ternyata menyebabkan turunnya penggunaan hutang, sedangkan penggunaan hutang pada titik tertentu dapat meningkatkan dan memaksimalkan nilai perusahaan. Turunnya nilai hutang terjadi karena perusahaan mengalami kesusahan untuk meminjam dana karena penggunaan modal mereka secara spesifik mengurangi kemungkinan pendanaan alternatif ketika terjadi kebangkrutan. Disisi lain, perusahaan dengan produk yang unik biasanya menghabiskan dananya pada resource and development agar membuat produk mereka semakin susah untuk ditiru dan memiliki biaya penjualan yang tinggi akibat promosi produk yang unik tersebut. Hal ini menyebabkan struktur modal dapat mempengaruhi hubungan uniqueness terhadap nilai perusahaan. Berdasarkan uraian tersebut, maka dapat dirumuskan hipotesis penelitian sebagai berikut:

\section{H7: Terdapat pengaruh yang signifikan uniqueness terhadap nilai perusahaan melalui struktur modal.}

\section{Pengaruh Tangibility Terhadap Nilai Perusahaan Melalui Struktur Modal}

Teori agensi berfokus pada penyelesaian dua masalah yang dapat terjadi pada hubungan agensi itu sendiri. Munculnya masalah keagenan ini ketika adanya konflik antara 
tujuan principal dan agent dan sulit atau mahal bagi principal untuk memastikan apa yang sebenarnya terjadi pada agent tersebut (Eisenhardt, 1989). Berdasarkan teori keagenan ini, akan muncul dorongan pada pemegang saham untuk berinvestasi secara tidak optimal karena adanya konflik antara kreditur dan pemegang saham. Kecenderungan ini membuat kreditur akan melakukan tindakan untuk melindungi diri mereka dengan mengharuskan aset berwujud sebagai jaminan (Chakraborty, 2010).

Perusahaan dengan tingkat aset berwujud yang tinggi akan memiliki jaminan untuk berhutang, jika perusahaan gagal membayar maka aset berwujud tersebut akan ditahan dan perusahaan terhindar dari kebangkrutan. Oleh karena itu ada terdapat hubungan positif antara banyak/tinggi nilai aset berwujud perusahaan pada nilai perusahaan. Pada sisi lain, kecenderungan manajer untuk menggunakan hutang yang lebih akibat adanya aset yang banyak Oleh karena itu, perusahaan yang memiliki aset berwujud yang rendah/sedikit akan menggunakan tingkat hutang yang tinggi untuk mengurangi penggunaan yang berlebihan dari manajer perusahaan. Berdasarkan uraian tersebut, maka dapat dirumuskan hipotesis penelitian sebagai berikut:

\section{Hs: Terdapat pengaruh yang signifikan tangibility terhadap nilai perusahaan melalui struktur modal.}

\section{Pengaruh Financial Flexibility Terhadap Nilai Perusahaan Melalui Struktur Modal}

Signalling theory menyatakan bahwa setiap event atau kejadian yang berupa pengumuman, aksi korporasi, atau publikasi mengenai sebuah perusahaan baik yang disengaja maupun tidak disengaja akan memiliki muatan informasi sebagai suatu sinyal yang disampaikan kepada pasar (Brigham dan Houston, 2006). Salah satu cara untuk mengurangi informasi asimetris adalah dengan memberikan sinyal kepada pihak luar yaitu memberikan informasi keuangan yang dapat dipercaya dan memiliki integritas dan akan mengurangi ketidak pastian mengenai prospek perusahaan yang akan datang (Juliana, 2012).

Fleksibilitas keuangan membantu perusahaan untuk mencegah kerusakan nilai dan memberikan perusahaan kemampuan untuk mengeksploitasi peluang investasi yang menjanjikan sehinggameningkatkan nilai perusahaan. Kemudian, perusahaan yang memiliki hutang memang mendapatkan keuntungan dari adanya penghematan pajak, namun pada dasarnya perusahaan yang memiliki hutang yang tinggi mencerminkan bahwa perusahaan memiliki keuangan yang terbatas. Perusahaan akan mengelola kekuatan keuangan mereka melalui financial slack (keadaan dimana perusahaan memiliki dana yang berlebih) seperti uang tunai, aset riil dan sekuritas dipasar, sehingga perusahaan yang memiliki fleksibilitas 
keuangan yang lebih tinggi akan mencerminkan bahwa perusahaan memiliki tingkat hutang yang rendah. Berdasarkan uraian tersebut, maka dapat dirumuskan hipotesis penelitian sebagai berikut:

H9: Terdapat pengaruh yang signifikan flexibility financial terhadap nilai perusahaan melalui struktur modal.

\section{Pengaruh Struktur Modal Terhadap Nilai Perusahaan}

Trade Off Theory menjelaskan bahwa struktur modal optimal tercapai pada saat terjadi keseimbangan antara manfaat dan pengorbanan yang timbul akibat penggunaan utang (Mutamimah dan Rita, 2009). Pengeluaran bunga yang menyebabkan penggunaan hutang lebih murah dari pada menerbitkan saham, karena dengan penggunaan hutang, perusahaan mempunyai tax benefit.

Penggunaan hutang dapat umumnya digunakan untuk dapat meningkatkan nilai perusahaan (Permatasari \& Azizah, 2018). Adanya penggunaan hutang dapat memberikan keuntungan bagi perusahaan karena dapat mengurangi beban perusahaan dalam pembayaran pajak perusahaan, namun disisi lain penggunaan hutang akan membuat perusahaan memperoleh laba yang lebih sedikit karena adanya beban hutang yaitu bunga yang harus dibayar oleh perusahaan, oleh karena itu perusahaan perlu memperhatikan keputusan pendanaanya. Struktur atau komposisi modal harus diatur sedemikian rupa sehingga terjamin stabilitas finansial perusahaan, memang tidak ada ukuran yang pasti mengenai jumlah dan komposisi modal dari tiap-tiap perusahaan, tetapi pada dasarnya pengaturan terhadap struktur modal dalam pesahaan harus berorientasi pada tercapainya stabilitas finansial dan terjaminnya kelangsungan hidup perusahaan. Perusahaan dapat memilih struktur modal yang optimal dengan biaya modal yang rendah sehingga dapat menghasilkan laba yang lebih besar dan akan meningkatkan nilai perusahaan. Berdasarkan uraian tersebut, maka dapat dirumuskan hipotesis penelitian sebagai berikut:

\section{H10: Terdapat pengaruh yang signifikan struktur modal terhadap nilai perusahaan}

\section{METODE PENELITIAN}

Populasi penelitian ini adalah aneka sektor industri dari tahun 2015-2019. Sampel penelitian adalah seluruh perusahaan yang dipilih dengan metode purposive sampling. 
Berdasarkan kriteria tersebut, dipilih 33 perusahaan sebagai sampel penelitian ini. Metode pengumpulan data dalam penelitian ini adalah metode sampling. Pengumpulan data dilakukan dengan mengunduh laporan keuangan dan tahunan seluruh perusahaan sampel penelitian yang telah diaudit dan dipublikasikan dengan mengakses website resmi Bursa Efek Indonesia.

\section{Definisi Operasional Variabel}

\section{Nilai Perusahaan}

Nilai perusahaan merupakan persepsi investor terhadap tingkat keberhasilan perusahaan dan prospek perusahaan di masa depan yang sering dikaitkan dengan harga saham (Handayani, 2015). Price Book Value (PBV) digunakan untuk mengukur nilai perusahaan yang menggambarkan seberapa besar pasar menghargai nilai buku saham suatu perusahaan. Melalui PBV, investor dapat memprediksi apakah saham perusahaan tersebut terlalu mahal atau terlalu murah (Utomo, Andini, \& Raharjo, 2016). Maka rumus untuk mengetahui nilai PBV adalah sebagai berikut (Handayani, 2015):

$$
\text { PBV }=\frac{\text { Harga pasar per saham }}{\text { Nilai buku per lembar saham }}
$$

Dimana:

Nilai buku per lembar saham = total ekuitas $/$ jumlah sahan yang beredar

\section{Struktur Modal}

Struktur modal adalah kombinasi pembiayaan yang digunakanperusahaan yang terdiri hutang jangka panjang, saham preferen, dan modal pemegang saham (Weston dan Copeland, 2007).Dalam penelitian ini, struktur modal dijadikan sebagai variabel dependen kedua (Y).Instrumen yang dapat digunakan untuk menilai variabel ini adalahDebt to Equity Ratio(DER). Oleh karena itu, formula untuk menentukan DER adalah sebagai berikut (Pantow, Murni, \& Trang, 2015):

$$
\text { DER }=\frac{\text { Debt Total }}{\text { Equity Total }}
$$

\section{Uniqueness}

Keunikkan (uniqueness) suatu perusahaan merupakan karakteristik perusahaan dimana perusahaan memiliki produk yang unik (Chunhua \& Meiyan, 2013). Dalam penelitian ini, uniqueness dijadikan sebagai variabel independen pertama $\left(\mathrm{X}_{1}\right)$. Formula untuk menentukan uniqueness adalah sebagai berikut (Chunhua \& Meiyan, 2013):

$$
\text { Uniqueness }=\frac{\text { Beban Penjualan }}{\text { Total Penjualan }}
$$




\section{Tangibility}

Aset berwujud (tangbility) adalah sumber daya yang dimiliki perusahaan yang dapat dilihat bentuk fisiknya (Jooma \& Gwatidzo, 2013). Dalam penelitian ini, tangibilitydijadikan sebagai variabel dependen kedua $\left(\mathrm{X}_{2}\right)$. Formula untuk menentukan tangibilityadalah sebagai berikut(Titman \& Wessels, 1988):

$$
\text { Tangibility }=\frac{\text { Total Aset Berwujud }}{\text { Total Aset }}
$$

Financial Flexibility

Fleksibilitas keuangan adalah kemampuan perusahaanuntuk memperolehkeuangannya agarmemiliki kekuatan dalam menghadapi kejadian masa depan yang tidak terduga sehingga dapat memaksimalkan nilai perusahaan (Cherkasova \& Kuzmin, 2018). Dalam penelitian ini, variabel ini dijadikan sebagai variabel independen ketiga $\left(\mathrm{X}_{3}\right)$.Formula untuk menentukan flexibility financialadalah sebagai berikut (Alipour, Mohammadi, \& Derakhshan, 2015):

$$
\text { Flexibility Financial }=\frac{\text { Laba ditahan }}{\text { Total aset }}
$$

\section{Metode Analisis Data}

Metode analisis yang digunakan dalam penelitian ini adalah SEM Structural Equation Modeling (SEM) atau model persamaan struktural dengan menggunakan program Warp-PLS (Partial Least Square) untuk menguji hubungan antar variabel. Terdapat tiga uji dalam analisis Warp-PLS yaitu measurement model (outer model), structural model (inner model) dan pengujian hipotesis (Ghozali, 2008):

\section{HASIL PENELITIAN DAN PEMBAHASAN}

\section{Analisis Deskriptif}

Tabel 2.

\begin{tabular}{|c|c|c|c|c|c|}
\hline & $\mathbf{N}$ & Minimum & Maximum & Mean & Std. Deviation \\
\hline PBV & 165 & $-2,32$ & 6,80 & ,7059 & 1,04429 \\
\hline DER & 165 & $-5,12$ & 13,21 & ,8117 & 1,80146 \\
\hline Uniqueness & 165 &, 00 & 1,54 & , 1023 & ,22894 \\
\hline Tangibility & 165 & ,00 & 6,09 & ,5427 & ,47338 \\
\hline Flex_Financial & 165 & $-9,52$ & 2,36 &,- 2026 & 1,69505 \\
\hline
\end{tabular}

Hasil Uji Statistik Deskriptif

Sumber: Hasil Olahan (2020).

\section{Hasil Analisis Partial Least Square (PLS)}

Hasil Pengujian Measurement Model (Outer model) 
Pengujian ini digunakan untuk menentukan hubungan antara variabel laten dan indikator-indikator. Evaluasi model pengukuran (outer model/measurement model) dalam penelitian ini menggunakan pengujian Model fit Indices dengan 10 kriteria, hasil pengujian menunjukkan bahwa model penelitian diterima dan cocok digunakan pada tahap selanjutnya.

\section{Tabel 3}

\section{Hasil Pengujian Measurement Model (Outer model)}

\begin{tabular}{|c|c|c|c|c|}
\hline Model Fit and Quality Indices & Indeks & P-value & Kriteria & Keterangan \\
\hline Average Path Coefficient (APC) & 0,332 & $\mathrm{P}=0,001$ & $\mathrm{P}<0,05$ & Diterima \\
\hline Average R-Squared (ARS) & 0,771 & $\mathrm{P}<0,001$ & $\mathrm{P}<0,05$ & Diterima \\
\hline Average Adjusted R-Squared (AARS) & 0,765 & $\mathrm{P}<0,001$ & $\mathrm{P}<0,05$ & Diterima \\
\hline Average Block VIF (AVIF) & 1,912 & \multirow{2}{*}{\multicolumn{2}{|c|}{$\begin{array}{c}\leq 5 \text { dan } \\
\text { idealnya } \leq 3,3 \\
\quad \leq 5 \text { dan } \\
\text { idealnya } \leq 3,3\end{array}$}} & Diterima \\
\hline Average Full Collinearity VIF (AFVIF) & 1,656 & & & Diterima \\
\hline TenenhausGoF (GoF) & 0,734 & \multicolumn{2}{|c|}{$\begin{array}{c}\text { Small } \geq 0,1 ; \text { Medium } \geq \\
0,25 ; \text { Large } \geq 0,36\end{array}$} & Large \\
\hline Sympson's Paradox Ratio (SPR) & 1,000 & \multicolumn{2}{|c|}{$\geq 0,7$} & Diterima \\
\hline R-Squared Contribution Ratio (RSCR) & 1,000 & \multicolumn{2}{|c|}{$\geq 0,9$} & Diterima \\
\hline Statistical Suppression Ratio (SSR) & 1,000 & \multicolumn{2}{|c|}{$\geq 0,7$} & Diterima \\
\hline Nonlinear Bivariate Causality Direction Ratio (NLBCDR) & 1,000 & \multicolumn{2}{|c|}{$\geq 0,7$} & Diterima \\
\hline
\end{tabular}

Sumber: Hasil Olahan (2020).

\section{Hasil Pengujian Inner Model}

Evaluasi model structural (inner model) dapat dievaluasi dengan menggunakan $\mathrm{R}^{2}(\mathrm{R}$ Square) yang digunakan untuk mengukur tingkat variasi perubahan variabel independen terhadap variabel dependen.

\section{Tabel 4}

Hasil Pengujian R-Square $\left(\mathbf{R}^{2}\right)$

\begin{tabular}{ccc}
\hline Struktur & R-squared & Adjusted R-squared \\
\hline DER & 0,920 & 0,918 \\
PBV & 0,621 & 0,612 \\
\hline
\end{tabular}

Sumber: Hasil Olahan (2020).

Berdasarkan tabel 4., maka diperoleh nilai Adjusted $R^{2}$ dengan variabel dependen struktur modal (DER) sebesar 0,918 artinya sebesar 91,8\% variable struktur modal dipengaruhi oleh uniqueness, tangibility dan financial flexibility. Kemudian diperoleh nilai Adjusted $R^{2}$ dengan variabel dependen nilai perusahaan (PBV) sebesar 0,612 artinya sebesar $61,2 \%$ variabel nilai perusahaan dipengaruhi oleh uniqueness, tangibility, financial flexibility dan struktur modal. Adapun nilai R square keseluruhan model analisis jalur dapat dicari menggunakan rumus sebagai berikut:

$$
\begin{aligned}
\mathrm{R}^{2} \mathrm{~m} & =1-\left(1-\mathrm{R}^{2}{ }_{1}\right)\left(1-\mathrm{R}^{2}{ }_{2}\right) \\
& =1-(1-0,920)(1-0,621)
\end{aligned}
$$




$$
=1-0,0303=0,969 \text { atau } 96,9 \%
$$

\section{Pengujian Hipotesis}

\section{Tabel 5}

\section{Hasil Pengujian Hipotesis}

\begin{tabular}{cccccccc}
\hline Hipotesis & $\begin{array}{c}\text { Path } \\
\text { Coefficients }\end{array}$ & P Value & Keputusan & Hipotesis & $\begin{array}{c}\text { Path } \\
\text { Coefficients }\end{array}$ & P Value & Keputusan \\
\hline H1 & $-0,04$ & 0,33 & $\begin{array}{c}\text { Tidak } \\
\text { Berpengaruh }\end{array}$ & H6 & $-0,00$ & 0,50 & Tidak Berpengaruh \\
H2 & 0,92 & $<0,01$ & Berpengaruh & H7 & $-0,006$ & 0,456 & Tidak Berpengaruh \\
H3 & $-0,16$ & $<0,01$ & Berpengaruh & H8 & 0,161 & 0,001 & Berpengaruh \\
H4 & 0,56 & $<0,01$ & Berpengaruh & H9 & $-0,029$ & 0,301 & Tidak Berpengaruh \\
H5 & 0,46 & $<0,01$ & Berpengaruh & H10 & $-0,18$ & 0,01 & Berpengaruh \\
\hline
\end{tabular}

Sumber: Hasil Olahan (2020).

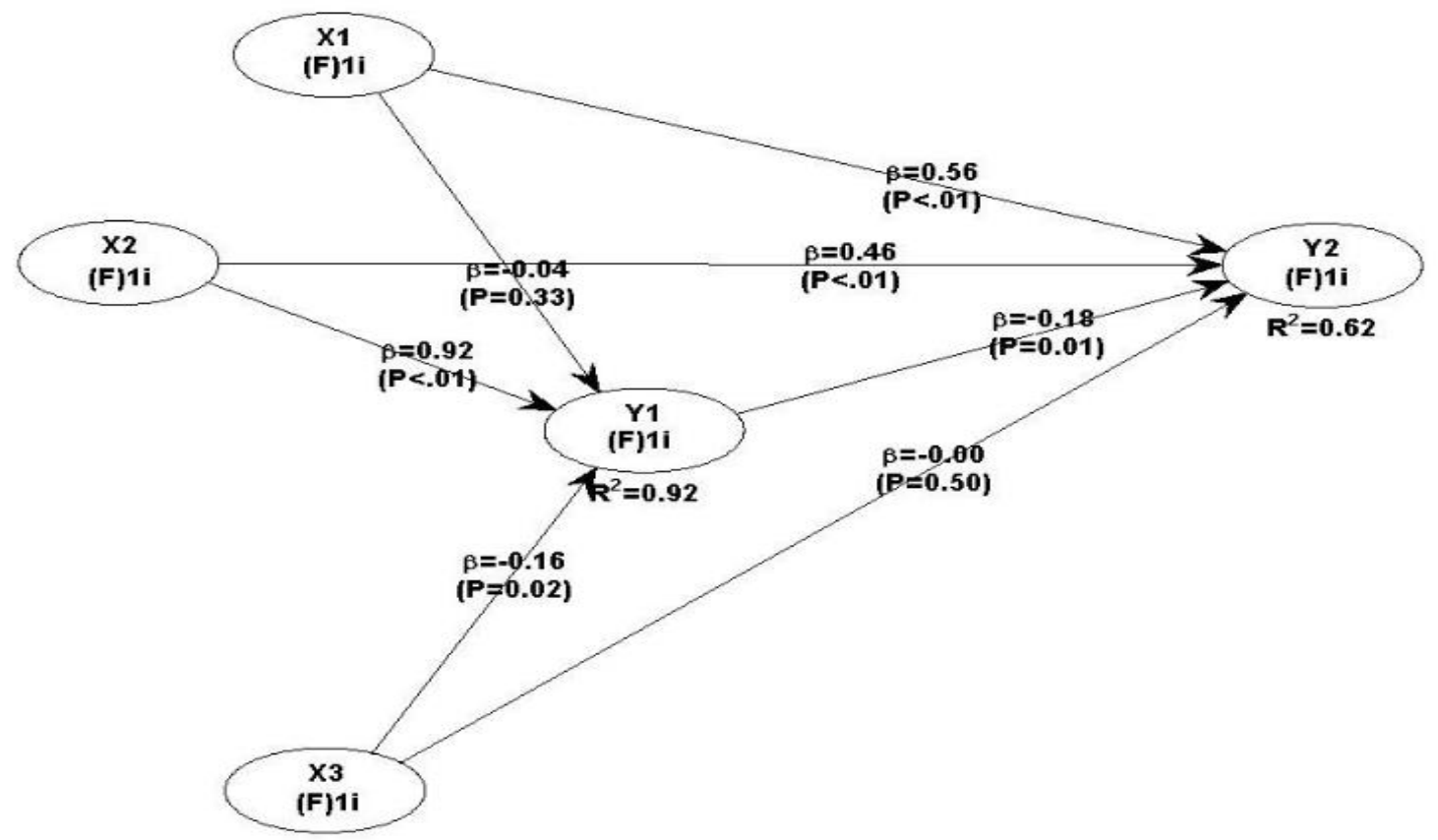

Sumber: Hasil Olahan (2020)

\section{Pengaruh Uniqueness Terhadap Struktur Modal}

Hasil penelitian ditemukan bahwa uniqueness tidak berpengaruh signifikan dan negatif terhadap struktur modal karena perusahaan yang memiliki produk yang unik tidak menjadi faktor penting bagi kreditor untuk meminjamkan dananya kepada perusahaan, sehingga tidak memberikan pengaruh kepada tingkat penggunaan hutang. Hasil penelitian ini didukung oleh penelitian yang dilakukan oleh Yanti, Ratnawati, \& Djumahir (2018) yang menunjukkan bahwa uniqueness tidak berpengaruh terhadap struktur modal perusahaan.

Hasil penelitian ini sesuai dengan resoursed based theory menjelaskan bahwa perusahaan dapat memperoleh keunggulan bersaing berkelanjutan ketika perusahaan menciptakan strategi/produk yang bernilai dan tidak dapat ditiru oleh perusahaan lainnya (Barney, 1991). Namun sumber daya yang unik dan sulit ditiru akan memberikan beban biaya 
kepada pelanggan, pemasok dan pekerja, selain itu perusahaan juga mengalami kesusahan untuk meminjam dana karena penggunaan modal mereka secara spesifik mengurangi kemungkinan pendanaan alternatif ketika terjadi kebangkrutan.

Hasil ini juga didukung oleh hasil analisis deskriptif yang menunjukkan adanya hubungan antara uniqueness dan struktur modal. Selama periode amatan tingkat uniqueness pada sektor aneka industri terus mengalami penurunan secara terus menerus namun penggunaan hutang semakin meningkat selama periode tersebut. Hal ini menandakan bahwa uniqueness dan struktur modal memiliki hubungan yang negatif.

\section{Pengaruh Tangibility Terhadap Struktur Modal}

Hasil penelitian ditemukan bahwa tangibility berpengaruh signifikan dan positif terhadap struktur modal karena perusahaan yang memiliki aset berwujud yang lebih banyak akan memiliki banyak jaminan untuk meminjam dana kepada kreditur. Oleh karena itu aset berwujud yang semakin tinggi akan memberikan peluang menggunakan hutang yang lebih tinggi juga. Hasil penelitian ini didukung oleh penelitian yang oleh Handoo\& Sharma (2014) dan Jooma \& Gwatidzo (2013) yang menunjukkan bahwa aset berwujud yang disebut juga dengan tangibility berpengaruh terhadap tingkat hutang perusahaan.

Hasil penelitian ini didukung oleh teori agensi yang mengemukakan bahwa munculnya masalah keagenan ini ketika adanya konflik antara tujuan principal dan agent dan sulit atau mahal bagi principal untuk memastikan apa yang sebenarnya terjadi pada agent tersebut (Eisenhardt, 1989). Berdasarkan teori keagenan ini, akan muncul dorongan pada pemegang saham untuk berinvestasi secara tidak optimal karena adanya konflik antara kreditur dan pemegang saham. Kecenderungan ini membuat kreditur akan melakukan tindakan untuk melindungi diri mereka dengan mengharuskan aset berwujud sebagai jaminan (Chakraborty, 2010).

Hasil penelitian ini didukung oleh teori agensi yang mengemukakan bahwa munculnya masalah keagenan ini ketika adanya konflik antara tujuan principal dan agent dan sulit atau mahal bagi principal untuk memastikan apa yang sebenarnya terjadi pada agent tersebut (Eisenhardt, 1989). Berdasarkan teori keagenan ini, akan muncul dorongan pada pemegang saham untuk berinvestasi secara tidak optimal karena adanya konflik antara kreditur dan pemegang saham. Kecenderungan ini membuat kreditur akan melakukan tindakan untuk melindungi diri mereka dengan mengharuskan aset berwujud sebagai jaminan (Chakraborty, 2010). 


\section{Pengaruh Financial Flexibility Terhadap Struktur Modal}

Hasil penelitian ditemukan bahwa financial flexibility berpengaruh signifikan dan negatif terhadap struktur modal karena perusahaan yang memiliki kekuatan keuangan cenderung memiliki dana yang berlebih. Adanya dana yang berlebih ini dapat digunakan oleh perusahaan untuk melakukan kegiatan operasional lainnya tanpa menggunakan dana dari pihak lain, sehingga tingkat fleksibilitas keuangan perusahaan berpengaruh negatif terhadap tingkat penggunaan hutang. Hasil penelitian ini didukung oleh penelitian yang dilakukan oleh Alipour, Mohammadi, \& Derakhshan (2015) dan Bauer (2004) yang menunjukkan bahwa fleksibilitas keuangan berpengaruh negatif terhadap struktur modal.

Hasil penelitian ini didukung oleh signalling theory menyatakan bahwa setiap informasi keuangan perusahaan yang publikasikan baik yang disengaja maupun tidak disengaja akan memiliki muatan informasi sebagai suatu sinyal yang disampaikan kepada pasar (Brigham dan Houston, 2006). Informasi keuangan perusahaan yang biasanya di publikasikan oleh perusahaan adalah laporan keuangan tahunan. Hal ini dilakukan untuk mengurangi informasi asimetris adalah dengan memberikan sinyal kepada pihak luar yaitu memberikan informasi keuangan yang dapat dipercaya dan memiliki integritas dan akan mengurangi ketidakpastian mengenai prospek perusahaan yang akan datang (Juliana, 2012).

Hasil penelitian ini juga selaras dengan hasil analisis deskriptif yang menunjukkan bahwa financial flexibility perusahaan pada sektor aneka industri ini terus mengalami penurunan dan bernilai negatif selama 5 tahun terturut-turut. Apabila dibandingkan dengan tingkat penggunaan hutang selama periode amatan, maka ditemukan bahwa tingkat penggunaan hutang terus mengalami peningkatan. Oleh karena itu berdasarkan hasil analisis deskriptif ditemukan bahwa financial flexibility memiliki hubungan yang negatif dengan struktur modal.

\section{Pengaruh Uniqueness Terhadap Nilai Perusahaan}

Hasil penelitian ditemukan bahwa uniqueness berpengaruh signifikan dan positif terhadap nilai perusahaan karena perusahaan yang memiliki keunikkan akan mempunyai keunggulan kompetitif didalam pasar dan keunggulan ini dapat menarik perhatian investor karena dianggap mampu memberikan keuntungan yang besar sehingga investor akan berinvestasi pada perusahaan dan akan meningkatkan nilai perusahaan. Hasil penelitian ini juga didukung oleh hasil penelitian yang dilakukan oleh Hoberg \& Phillips (2012) dan Wen \& Tikoo (2020) menjelaskan bahwa tingkat keunikan produk yang dimiliki oleh perusahaan akan mempengaruhi nilai perusahaan. 
Hasil penelitian ini didukung oleh resoursed based theory yang menjelaskan bahwa perusahaan dapat memperoleh keunggulan bersaingnya ketika perusahaan menciptakan strategi/produk yang bernilai dan tidak dapat ditiru oleh perusahaan lainnya. Perusahaan yang emiliki sumber daya yang unik dan sulit ditiru oleh para pesaingnya (superior resources) dan diolah melalui kapabilitas perusahaan yang baik, maka perusahaan akan mampu meraih keunggulan bersaingnya yang akan mengarah kepada peningkatan nilai perusahaan (Barney, 1991).

Hasil penelitian ini juga selaras dengan hasil analisis deskriptif yang menjelaskan bahwa adanya hubungan antara unqiueness dan nilai perusahaan. Perkembangan unqiueness selama periode amatan terus mengalami penurunan dan hal ini berbanding lurus dengan nilai perusahaan pada periode amatan yang sama yang juga mengalami penurunan yang signifikan. Oleh karena itu dapat dikatakan bahwa unqiueness memiliki hubungan yang positif dengan nilai perusahaan.

\section{Pengaruh Tangibility Terhadap Nilai Perusahaan}

Hasil penelitian ditemukan bahwa tangibility berpengaruh signifikan dan positif terhadap nilai perusahaan karena perusahaan yang memiliki aset berwujud yang banyak akan memberikan peluang bagi perusahaan untuk mengembangkan kegiatan perusahaan dengan menjamin aset berwujud tersebut untuk memperoleh dana sehingga dapat meningkatkan nilai perusahaan. Hasil penelitian ini juga didukung oleh penelitian yang dilakukan oleh Ariyanti (2019) dan Purba, Sagala, \& Saragih (2018) menunjukkan bahwa tangibility berpengaruh signfikan terhadap nilai perusahaan.

Hasil penelitian ini didukung oleh teori agensi yang mengemukakan bahwa akan muncul dorongan pada pemegang saham untuk berinvestasi secara tidak optimal karena adanya konflik antara kreditur dan pemegang saham. Kecenderungan ini membuat kreditur akan melakukan tindakan untuk melindungi diri mereka dengan mengharuskan aset berwujud sebagai jaminan. Adanya jaminan ini tentu dapat mengurangi konflik antara kreditur dan pemegang saham sehingga perusahaan dapat lebih optimal melaksanakan kegiatan perusahaan dan meningkatkan nilai perusahaan (Chakraborty, 2010).

Hasil penelitian ini jugu selaras dengan hasil analisis deskriptif yang menunjukkan bahwa adanya hubungan antara tangibility dan nilai perusahaan pada sektor aneka industri. Kepemilikan aset berwujud pada sektor ini selama periode amatan cenderung berfluktuasi dan 
tidak mengalami peningkatan selaras dengan semakin turunnya nilai perusahaan pada sektor ini. Oleh karena, tangibility memiliki hubungan yang positif terhadap nilai perusahaan.

\section{Pengaruh Financial Flexibility Terhadap Nilai Perusahaan}

Hasil penelitian ditemukan bahwa financial flexibility tidak berpengaruh signifikan dan negatif terhadap nilai perusahaan karena perusahaan yang memiliki tingkat financial flexibility yang tinggi menunjukkan bahwa adanya ketersediaan kas didalam perusahaan yang berlebih. Hal ini dianggap sebagai ketidak-mampuan perusahaan dalam mengelelo kas dan investor akan menilai ini sebagai hal yang merugikan karena perusahaan tidak menggunakan modal yang diberikan dengan maksimal sehingga akan menurunkan nilai perusahaan. Hasil penelitian ini juga didukung oleh penelitian yang dilakukan Vaan (2011) yang menemukan bahwa tingkat fleksibilitas keuangan perusahaan tidak berpengaruh terhadap nilai perusahaan.

Hasil penelitian ini selaras dengan signalling theory menyatakan bahwa setiap pengumuman maupun publikasi mengenai sebuah perusahaan baik yang disengaja maupun tidak disengaja akan memiliki muatan informasi sebagai suatu sinyal yang disampaikan kepada pasar. Publikasi keuangan perusahaan dapat memberikan signal kepada pihak luar perusahaan mengenai kelenturan keuangan perusahaan sehingga dapat membantu investor untuk mengambil keputusan yang juga akan mempengaruhi nilai perusahaan (Brigham dan Houston, 2006).

Hasil penelitian ini juga didukung oleh hasil analisis deskriptif yang menjelaskan bahwa tingkat fleksibilitas keuangan pada perusahaan di sektor aneka industri ini cenderung berfluktasi dan bernilai negatif selama periode amatan sedangkan nilai perusahaan mengalami penurunan yang signifikan dan terus menerus selama periode amatan. Oleh karena itu, dapat dikatakan bahwa financial flexibility memiliki hubungan yang negatif dengan nilai perusahaan.

\section{Pengaruh Uniqueness Terhadap Nilai Perusahaan Melalui Struktur Modal}

Hasil penelitian ditemukan bahwa uniqueness tidak berpengaruh signifikan dan negatif terhadap nilai perusahaan melalui struktur modal karena apabila kegiatan menghasilkan produk yang unik tersebut dilakukan dengan menggunakan hutang maka keunikkan dan keunggulan kompetitif didalam pasar tidak dapat mempengaruhi nilai perusahaan yang disebabkan oleh semakin besarnya biaya dan tingkat risiko dari penggunaan hutang pada kegiatan yang spesifik tersebut. Hasil penelitian ini juga didukung oleh hasil penelitian yang dilakukan oleh Yanti, Ratnawati, \& Djumahir (2018) dan Ang (1991) yang 
menemukan bahwa uniqueness tidak berpengaruh terhadap nilai perusahaan melalui struktur modal.

Hasil penelitian ini didukung oleh resoursed based theory yang menjelaskan bahwa perusahaan dapat memperoleh keunggulan bersaingnya ketika perusahaan menciptakan strategi/produk yang bernilai dan tidak dapat ditiru oleh perusahaan lainnya. Perusahaan yang memiliki sumber daya yang unik dan sulit ditiru oleh para pesaingnya (superior resources) dan diolah melalui kapabilitas perusahaan yang baik, maka perusahaan akan mampu meraih keunggulan bersaingnya yang akan mengarah kepada peningkatan nilai perusahaan. Namun sumber daya yang unik dan sulit ditiru akan menambah beban biaya yang lebih besar dan tidak memungkinkan perusahaan untuk menambah penggunaan hutangnya karena akan memberikan beban yang semakin tinggi dan risiko kerugian yang semakin besar.(Barney, 1991).

Hasil penelitian ini selaras dengan hasil analisis deskriptif yang menjelaskan bahwa keunikkan perusahan pada sektor aneka industri selama periode amatan mengalami penurunan namun tingkat penggunaan hutang semakin meningkat. Hal ini menunjukkan bawha adanya tingkat keunikkan yang semakin rendah namun ditopang dengan penggunaan hutang yang semakin tinggi akan membuat nilai perusahaan menjadi turun secara terus menerus selama periode amatan. Oleh karena itu terdapat hubungan yang negatif antara uniqueness terhadap nilai perusahaan melalui struktur modal.

\section{Pengaruh Tangibility Terhadap Nilai Perusahaan Melalui Struktur Modal}

Hasil penelitian ditemukan bahwa tangibility berpengaruh signifikan dan positif terhadap nilai perusahaan melalui struktur modal karena perusahaan yang memiliki aset berwujud yang banyak akan memberikan peluang bagi perusahaan untuk mengembangkan kegiatan perusahaan dengan menjamin aset berwujud tersebut untuk memperoleh dana dari perbankan maupun lembaga keuangan lainnya, selain itu penggunaan hutang dapat memberikan keuntungan bagi perusahaan karena dapat mengurangi beban perusahaan sehingga dapat meningkatkan nilai perusahaan. Hasil penelitian ini juga didukung oleh hasil penelitian yang dilakukan oleh Handoo\& Sharma (2014) dan Sutrisno (2016) menunjukkan bahwa tangibility berpengaruh terhadap nilai perusahaan melalui struktur modal perusahaan.

Hasil penelitian ini didukung oleh agency theory yang mengemukakan bahwa akan muncul dorongan pada pemegang saham untuk berinvestasi secara tidak optimal karena adanya konflik antara kreditur dan pemegang saham. Kecenderungan ini membuat kreditur akan melakukan tindakan untuk melindungi diri mereka dengan mengharuskan aset berwujud 
sebagai jaminan. Adanya jaminan ini tentu dapat mengurangi konflik antara kreditur dan pemegang saham sehingga perusahaan dapat lebih optimal melaksanakan kegiatan perusahaan dan meningkatkan nilai perusahaan (Chakraborty, 2010).

Hasil penelitian ini juga selaras dengan hasil analisis deskriptif yang menunjukkan bahwa tangibility pada perusahaan di sektor aneka industri ini cenderung berfluktuasi dan tidak mengalami peningkatan yang signifikan namun hutangnya semakin meningkat yang menyebabkan penurunan nilai perusahaan. Hal ini disebebakan oleh perusahaan terus menambah penggunaan hutangnya namun tidak memiliki tambahan aset berwujud yang mengisyaratkan penggunaan hutang pada sektor ini bukan diinvestasikan pada asetnya sehingga menurunkan nilai perusahaan. 


\section{Pengaruh Financial Flexibility Terhadap Nilai Perusahaan Melalui Struktur Modal}

Hasil penelitian ditemukan bahwa financial flexibility tidak berpengaruh signifikan dan negatif terhadap nilai perusahaan melalui struktur modal karena perusahaan yang memiliki tingkat financial flexibility yang rendah menunjukkan bahwa kekuatan keuangan dalam perusahaan yang lemah dalam menghadapi berbagai kondisi tidak terduga sehingga tidak memungkinkan perusahaan untuk meningkatkan hutang karena akan menyebabkan beban perusahaan semakin tinggi dan membuat keuangan perusahan semakin sulit dan lemah yang menyebabkan nilai perusahaan turun. Hasil penelitian ini juga didukung oleh penelitian yang dilakukan Vaan (2011) dan Alipour, Mohammadi, \& Derakhshan (2015) menunjukkan bahwa fleksibilitas keuangan tidak berpengaruh dan negatif terhadap nilai perusahaan melalui struktur modal.

Hasil penelitian ini selaras dengan signalling theory menyatakan bahwa setiap pengumuman maupun publikasi mengenai sebuah perusahaan baik yang disengaja maupun tidak disengaja akan memiliki muatan informasi sebagai suatu sinyal yang disampaikan kepada pasar, salah satu bentuk publikasi tersebut adalah publikasi keuangan perusahaan. Laporan keuangan yang disampaikan oleh perusahaan memiliki banyak informasi mengenai keadaan perusahaan yang dapat memberikan signal kepada pihak luar perusahaan mengenai kekuatan keuangan perusahaan sehingga dapat membantu investor untuk mengambil keputusan (Brigham dan Houston, 2006).

Hasil penelitian ini juga didukung oleh hasil analisis deskriptif yang menjelaskan bahwa tingkat fleksibilitas keuangan pada perusahaan di sektor aneka industri ini cenderung berfluktasi dan bernilai negatif selama periode amatan, namun penggunaan hutang yang dilakukan oleh perusahaan semakin meningkat. Hal ini akan menyebabkan nilai perusahaan mengalami penurunan yang signifikan dan terus menerus selama periode amatan. Oleh karena itu, dapat dikatakan bahwa financial flexibility memiliki hubungan yang negatif dengan nilai perusahaan melalui struktur modal.

\section{Pengaruh Struktur Modal Terhadap Nilai Perusahaan}

Hasil penelitian ditemukan bahwa struktur modal berpengaruh signifikan dan negatif terhadap nilai perusahaan karena perusahaan yang memiliki tingkat penggunaan hutang yang terlalu tinggi sehingga melebihi struktur modal yang optimal akan membuat penurunan pada pada nilai perusahaan. Hasil penelitian ini selaras dengan trade off theory yang menjelaskan bahwa struktur modal optimal tercapai pada saat terjadi keseimbangan antara manfaat dan pengorbanan yang timbul akibat penggunaan utang. Pengeluaran bunga yang menyebabkan penggunaan hutang lebih murah daripada menerbitkan saham, karena dengan penggunaan 
hutang, perusahaan mempunyai tax benefit sehingga dapat meningkatkan nilai perusahaan. Namun apabila penggunaan hutang sudah melebih titik optimal maka akan menurunkan nilai perusahaan (Mutamimah dan Rita, 2009).

Hasil penelitian ini juga didukung oleh hasil analisis deskriptif yang menunjukkan adanya penggunaan hutang pada perusahaan di sektor aneka industri ini terus mengalami peningkatan terturut-turur selama periode amatan, sedangkan nilai perusahaan selama peridoe amatan juga terus mengalami penurunan yang signifikan. Oleh karena itu dapat dikatakan bahwa struktur modal memiliki hubungan negatif terhadap nilai perusahaan. Adanya penggunaan hutang yang dilakukan oleh perusahaan pada sektor ini sebenarnya dapat memberikan keuntungan bagi perusahaan karena dapat mengurangi beban perusahaan dalam pembayaran pajak perusahaan. Namun disisi lain penggunaan hutang akan membuat perusahaan memperoleh laba yang lebih sedikit karena adanya beban hutang yaitu bunga yang harus dibayar oleh perusahaan, oleh karena itu perusahaan perlu memperhatikan keputusan pendanaanya.

Adanya peningkatan nilai DER secara terus menerus selama 5 tahun terkahir pada perusahaan di sektor aneka industri ini menunjukkan komposisi jumlah hutang/kewajiban lebih besar dibandingkan dengan jumlah seluruh modal bersih yang dimilikinya, sehingga mengakibatkan beban perusahaan terhadap pihak luar besar juga. Selain itu juga dapat mencerminkan bahwa hutang digunakankan sudah berlebihan dan dapat memberikan risiko keuangan. Hasil penelitian ini juga didukung oleh penelitian yang dilakukan oleh Pantow et al., (2015), Hamidy et al., (2015) dan Aggarwal \& Padhan (2017) menjelaskan bahwa struktur modal yang optimal berpengaruh terhadap nilai perusahaan.

\section{SIMPULAN}

Berdasarkan hasil penelitian, maka dapat disimpulkan bahwa uniqueness tidak berpengaruh signifikan dan negatif terhadap struktur modal, tangibility berpengaruh signifikan dan positif terhadap struktur modal, financial flexibility berpengaruh signifikan dan negatif terhadap struktur modal, uniqueness dan tangibility berpengaruh signifikan dan positif terhadap nilai perusahaan, financial flexibility tidak berpengaruh signifikan dan negatif terhadap nilai perusahaan, tangibility berpengaruh signifikan dan positif terhadap nilai perusahaan melalui struktur modal, uniqueness dan financial flexibility tidak berpengaruh signifikan dan negatif terhadap nilai perusahaan melalui struktur modal dan struktur modal berpengaruh signifikan dan negatif terhadap nilai perusahaan. 
Penelitian ini memiliki nilai $R$-Squre pada nilai perusahaan yang masih rendah. Oleh karena itu, peneliti selanjutnya dapat menggunakan variabel lainnya dalam menentukan faktor-faktor yang mempengaruhi nilai perusahaan, seperti risiko perusahaan dan aset tidak berwujud.dan Penelitian ini juga berfokus pada produk manufaktur di sektor aneka industri dalam menilai keunikkan yang ditawarkan oleh perusahaan.

Peneliti selanjutnya dapat menggunakan variabel lainnya dalam menentukan faktorfaktor yang mempengaruhi nilai perusahaan dan dapat menggunakan objek penelitian lainnya seperti pada perusahaan jasa sehingga dapat memberikan hasil yang lebih menarik dan berbeda. Perusahaan pada sektor aneka industri diharapkan dapat secara maksimal mempertahankan atau meningkatkan pengelolan aset berwujud, kekuatan keuangan dan menjaga penggunaan hutang agar tetap berada pada titik struktur modal yang optimal sehingga dapat meningkatkan nilai perusahaan.

\section{REFERENSI}

Alipour, M., Mohammadi, M. F. S., \& Derakhshan, H. (2015). Determinants of capital structure: An empirical study of firms in Iran. International Journal of Law and Management, 57(1), 53-83. https://doi.org/10.1108/IJLMA-01-2013-0004

Ang, J. S. (1991). Small Business Uniqueness and the Theory of Financial Management. The Journal of Entrepreneurial Finance, 1(1), 1-13.

Ariyanti, R. (2019). Pengaruh Tangible Asset, Roe, Firm Size, Liquidty Terhadap Price Book Value Dengan Struktur Modal Sebagai Variabel Intervening Pada Perusahaan Perbankan. BALANCE: Economic, Business, Management and Accounting Journal, 16(1). https://doi.org/10.30651/blc.v16i1.2450

Bank Indonesia. (2018). Laporan Perekonomian Indonesia. Retrieved from Search Results\%0AWeb results\%0A\%0Alaporan perekonomian indonesia 2018 issn 05222572 - Bank ...www.bi.go.id > perekonomian > Documents > 14_LPI2018

Bauer, P. (2004). Determinants of capital structure empirical evidence from the Czech Republic. Finance a Uver - Czech Journal of Economics and Finance, 54(1), 2-21.

BPS. (2018). Badan Pusat Statistik Produk Domestik Bruto (PDB) 2018. Jakarta.

Chakraborty, I. (2010). Capital structure in an emerging stock market: The case of India. Research in International Business and Finance, 24(3), 295-314. https://doi.org/10.1016/j.ribaf.2010.02.001

Cherkasova, V., \& Kuzmin, E. (2018). Financial flexibility as an investment efficiency factor in Asian companies. Gadjah Mada International Journal of Business, 20(2), $137-$ 164. https://doi.org/10.22146/gamaijb.26239 
Chunhua, W., \& Meiyan, S. (2013). Relationship between Capital Structure and Performance Evidence based on Information Technology Industry. (Cse), 330-333. https://doi.org/10.2991/cse.2013.74

Ghozali, I. (2006). Aplikasi Analisis Multivariete Dengan Program SPSS 23 (Empat). Semarang: Badan Penerbit Universitas Diponegoro.

Ghozali, I. (2008). Structural Equation Modeling, Metode Alternatif dengan Partial Least Square (PLS). Semarang: Badan Penerbit Universitas Diponegoro.

Hoberg, G., \& Phillips, G. M. (2012). Product Market Uniqueness, Organizational Form and Stock Market Valuations. SSRN Electronic Journal. https://doi.org/10.2139/ssrn.2160846

J.Fred Weston, \& Copeland, T. E. (2007). Manajemen Keuangan Jilid 1 dan 2. Jakarta: Binarupa Aksara.

Jooma, M. Y. H., \& Gwatidzo, T. (2013). Partial adjustment toward target capital structure: Evidence from selected African countries. Corporate Ownership and Control, 10(3 E,CONT4), 386-401.

Pantow, M. S., Murni, S., \& Trang, I. (2015). Analisa Pertumbuhan Penjualan, Ukuran Perusahaan, Return on Asset, Dan Struktur Modal Terhadap Nilai Perusahaan Yang Tercatat Di Indeks Lq 45. Jurnal Riset Ekonomi, Manajemen, Bisnis Dan Akuntansi, 3(1), 961-971. https://doi.org/10.35794/emba.v3i1.7801

Permatasari, D., \& Azizah, D. F. (2018). Pengaruh Struktur Modal Terhadap Nilai Perusahaan (Studi Pada Perusahaan Sub Sektor Makanan Dan Minuman Yang Terdaftar Di Bursa Efek Indonesia Tahun 2013-2016). Jurnal Administrasi Bisnis (JAB), 61(4), 100-106. Retrieved from administrasibisnis.studentjournal.ub.ac.id\%0A106

Purba, D., Sagala, L., \& Saragih, R. (2018). Pengaruh Profitabilitas, Asset Tangibility, Tingkat Pertumbuhan, dan Non-Debt Tax Shield Terhadap Struktur Modal serta Pengaruhnya Terhadap Nilai Perusahaan (Studi Kasus Pada Perusahaan Manufaktur Asia Tenggara). Jurnal Riset Inspirasi Manajemen Dan Kewirausahaan, 2(2), 115119. https://doi.org/10.35130/jrimk.v2i2.24

Sutrisno. (2016). Capital Structure Determinants and Their Impact on Firm Value: Evidence From Indonesia. Economics World, 4(4), 179-186. https://doi.org/10.17265/2328$7144 / 2016.04 .003$

Titman, S., \& Wessels, R. (1988). The Determinants of Capital Structure Choice. The Journal of Finance, 43(1), 1-19. https://doi.org/10.1111/j.1540-6261.1988.tb02585.x

Utomo, W., Andini, R., \& Raharjo, K. (2016). Pengaruh Leverage (DER), Price Book Value (PBV), Ukuran Perusahaan (Size), Return On Equity (ROE), Deviden Payout Ratio (DPR) Dan Likuiditas (CR) Terhadap Price Earning Ratio (PER) Pada Perusahaan Manufaktur Yang Listing di BEI Tahun 2009 - 2014. Journal Of Accounting, 2(2).

Vaan, R. de. (2011). The relationship between financial flexibility and firm value : University of Tilburg. 
Wen, Y., \& Tikoo, S. (2020). Corporate strategy uniqueness, analyst herding, and financing constraints. Strategic Organization, 1-21. https://doi.org/10.1177/1476127020928013

Yanti, N. N. S. A., Ratnawati, K., \& Djumahir. (2018). Pengaruh Variabel Determinan terhadap Struktur Modal dan Dampak Struktur Modal terhadap Nilai Perusahaan (Studi Empiris pada Perusahaan Sektor Manufaktur yang Terdaftar di Bursa Efek Indonesia). Jurnal Manajemen Dan Kewirausahaan, 6(2), 211-224. https://doi.org/10.26905/jmdk.v6i2.2210

Zhu, Y. (2012). Capital structure: The case of firms issuing debt. Australian Journal of Management, 37(2), 283-295. https://doi.org/10.1177/0312896211429159 